got a single bone, and am persuaded that the bed during that fimo was not onee lsid open by the tides. On the other hand, the excavations in the Thames valley are very extensive, and continually worked, so that, probably, most of the species have turned up which are there buried. There is certain proof of the depression of the Clacton area subsequently to the period when the mammalia were entombed, for the bed in which they lie is purely freshwater, and it is covered with several feet of brackish water beds, with small Serobieularia; and at the top of the section occurs a seam in which I found Cyrena fuminalis, associated with dwarfed Cardium edule, and a Paludina undistinguishable from lenta. Now a similar depression of the area seems to be shown at Grays, by the false bedded sand, No. 5 of Mr. Dawkins' section, ${ }^{1}$ overlying the mammaliferous gravel.

The Clacton deposit is a true valley deposit, cut out of the London clay, and an overlying gravel which Mr. Wood calls the "East Essex Gravel." This gravel, as I understand him, he supposes much newer than the Boulder-clay; but at any rate it cannot be older than the Middle Drift, and in either case it throws the Claeton deposit into Post-glacial times,

Hartion, Cambrimgr.

O. Fisplar.

\title{
BOS LONGIFRONS.
}

Sir,-Owing to my absence from England, I have only just enjoyed the pleasure of reading the memoir which my friend $\mathbf{M r}$. Boyd Dawkins has contributed to the "Quarterly Journal of the Geological Society," and which appears in their 91st No., p. 176. There are some passages in this to which I may reasonably be allowed to demur, and I therefore, while giving Mr. Boyd Dawking the utmost credit for the ability with which the case for the plaintiff has been stated, will at once proceed to open the defence.

The characters of Bos longifrons are elearly described by Mr. Dawkins, with such lucidity, in fact, that he is " unable to assign any characters of specific value to the animal." But I cannot allow that he shows sufficient cause why two out of the three other species of fossil English Bovines should be abandoned. In a memoir of eight pages, exactly twenty-one lines are devoted to the examination of the claims of Bos frontosus to specific distinction; whilst Bos trachoceros is utterly ignored. Both these species were found associated with Bos longifrons in a refuse heap in London Wall, by my friend Lieut.-Colonel A. Lane Fox, F.S.A., and the circumstances of their gisement have been accurately described by him in the "Journal Anthrop Soc. Lond.," Dec. 1866. Of their identification there can be no doubt, and the specimens will be gladly placed in Mr. Daw: kins' hands for description.

Mr. Dawkins' argument is as follows, - "A A very large number of skulls from the Irish turbaries in the Museum of the Royal Dublin Society show a marked gradation in size and form, and constitute

1 Quart. Journ. Geol. Soc. vol. xxiii. p. 94. 
an umbroken series with the Bos frontosus of Nilsson at one end, and the more common variety of Bos longifrons at the other. In consequence of this, I am unable to assign any characters of specific value to the animal. $\quad$ The Bos frontosus of Nilsson is proved by the series in Dublin, as stated above, to be a mere variety." Such, and such only, are the grounds on which Mr. Dawkins disposes of this species. He gives two measurements of skulls of individuals who confessedly appertain to Bos longifrons, and have no "Frontosine" characters, and eight measurements of horn-cores. No further are vouchsafed to us; none are even promised, though we learn that some detailed measurements of teeth and long bones are to be appended at the end of his third paper. The facts are not forthcoming, or at least are not shown, on which Bos frontosus can be eradicated from the catalogue. It is quite possible that the large series of longifrons remains in the Dublin and Oxford Museums may corroborate Mr. Dawkins' conclusion; those in the British Museum and Royal College of Surgeons Collections, to which Mr. Dawkins appeals, have nat led me, after most careful examination, to arrive at the same result. Science imperatively requires, not a mere sweeping assertion that Bos frontosus "cannot be made out" as a species, but a careful series of measurements of at least fifty specimeas, so that the "unbroken series" which Mr. Dawkins imagines to exist may be distinctly shown. Till evidence is really put in, Nilsson's species must be allowed to stand.

Mr. Dawkins' arguments in favour of the "affinity" of the old Aquitanian cave-dwellers "with the Esquimaux" do not appear to be of the strongest value. "The habit of sculpturing animals on their implements" is common in all savage races; "the carelessness about the remains of their dead relatives" is also predicable of many; "the fact that the food consisted chiefly of reindeer" only proves that reindeer was an accessible and plentiful food, and by no means denotes community of origin. Mr. Dawkins' argument is :-All who eat reindeer meat are "closely allied :" Esquimaux eat reindeer meat, and Aquitanian cave-dwellers ate reindeer meat: $\because$ Esquimaux and Aquitanian care-dwellers are "closely allied." At the present moment, English, Americans, Negroes, and Red Indians are feeding here on beef (when they can get it): yet there is no community of race. Mr. Dawkins' last statement regarding the small stature being "proved in the people of the Dordogne Caverns by the small-handed dagger figured by Messrs. Lartet and Christy in the Révue Archéologique" I must doubt. All who are acquainted with the small-griped swords of the existing Hindoos, and of many of the so-called Phcnician sepultures, will know that they are held in the hand in a very different way to that of our own swords, and that the smallness of the grip by no means connotes the size of the individual. I must not, however, discuss this matter further in a periodical devoted to geology.

Mr. Dawkins accuses Professor Owen of holding "contradictory opinions." In opposition to the first, that "the Romans imported into Britain their 'already domesticated cattle,' and our breeds are 
their descendants," he brings the statement that "Bos longifrons is the only ox found in the refuse heaps, in not one or two but all the camps, cities, villas, and cemeteries that bear the impress of Roman civilisation in Britain." In the first place, in one, at least, of the Roman camps (London Wall) Bos longifrons is not the only ox found, as B. frontosus and trochoceros are associated with it. Whatever Mr. Dawkins may say of Bos frontosus, I presume he will not slump $B$. trochoceros in gurgite vasto of his longifrons. In the second place, I fail to see how he can point out any difference between the characters of the Roman cattle, which he nowhere describes, and those of Bos longifrons, to which he is " unable to assign any characters of specific value." Where one factor is unknown, and the other undefined, it is difficult to perceive how any conclusion can be arrived at. Probably if Mr. Dawkins examines carefully a series of the bovine remains from Italian sepultures, he may consider these also to be longifrons. This fact remains to be proved.

Mr. Dawkins" first conclusion, that $B$. longifrons " has not yet been proved to have existed before the Pre-historic age, in the bone-caves and alluvia of which it is found abundantly," I must leave him to discuss with Professor Owen. His second conclusion, that " it is the ancestor of the small Highland and Welsh breeds," is self-evident, and unnecessary to be proved. I fail to see that Professor Owen's original opinion to this effect needed such a repetition, nor do I see any new arguments in favour adduced by Mr. Dawkins. When, however, he employs the expression that "it is essentially the animal with which the archæologists have to deal," I must humbly put in a plea in favour of the animal nature of man, and express my belief that up to the present time I thought that archæologists had to deal with human works, and human remains, as well as those of horses, goats, and sheep, when found with human relics. For the present, I must close this letter.

"La plaza al punto el buey desembaraza.

Quedando stros mas buejes en la plaza."

ARriaza.

C. Carter Blake.

Jafatí Mine, Chontales, Nigaragua, 4th December, 1867.

SULVER-FAHLERZ IN CORNWALL.

SrR,-Will you allow me space for a short reply to the letter of Mr. David Forbes contained in your last number? That gentleman seems to have quite misunderstood the object of my communication to the Geological Magazine of December last (p. 575), upon which he comments. The explanation I have to give is as follows :-

Mr. Forbes having stated that "the cupriferous tetrahedrite (occasionally containing traces of silver) has been found in small quantities at various localities in both England, Ireland, Scotland, and Wales," I believed he would be interested to know of the fact, that a cupriferons tetrahedrite, containing sufficient silver to render it of considerable commercial value, had been already worked in large quantity for some time past, at the Silver-vein mine in Cornwall. 